\title{
LIVING WITH THE SUN: ARCHITECTURE AND THE ASSOCIATION FOR APPLIED SOLAR ENERGY, 1954-1958
}

\author{
DANIEL BARBER \\ School of Architecture and Planning \\ University of Auckland \\ Private Bag 92019, Auckland, New Zealand \\ d.barber@auckland.ac.nz
}

\begin{abstract}
At the end of 1957, a group called the Association for Applied Solar Energy held an international competition for the design of a solar house, to be built in Phoenix, Arizona. In the mid-1950s before the development of the photo-voltaic cell - the use of solar energy in residential design was both an architectural project and a technological project; in no small part it was an investigation into architectural design as technology, engaging concerns over site orientation and cubic volumes as much as ideal angles for solar collection and methods of heat storage. The 1957 competition, called Living with the Sun, intended to exploit this connection between design and technology. Parallel with the development of modern architecture as an expression of a contemporary lifestyle, this early instance of solar architecture intended to allow innovation in design to produce a new relationship to technology and, by simple extrapolation, to the material, environmental, and political issues that accompanied the slow depletion of fossil fuel resources, a phenomenon already becoming clear in the immediate post-war context. Living with the Sun was thus a straightforward attempt, on the part of architects, to engage environmental problems.
\end{abstract}

Keywords: Solar Collectors, Modern Architecture.

\section{Living with the Sun}

At the end of 1957, a group called the Association for Applied Solar Energy held an international competition called Living with the Sun, calling on entrants to design a solar house for a site in Phoenix, Arizona. In the mid-1950s - before the development of the photo-voltaic cell - the use of solar energy in residential design was both an architectural project and a technological project; as this paper will demonstrate it was in no small part an investigation into architectural design as technology, engaging concerns over site orientation and cubic volumes as much as ideal angles for solar collection and methods of heat storage. Transformations in the concept of 'modern architecture' were, by this period, in part defined by residential design producing and representing a modern lifestyle. Richard Neutra's 1947 Kaufmann House, in Palm Springs, and Pierre Keonig's 1959 Case Study House \#22 are two of the best-known examples. Prominent design characteristics of both of these houses - including open plans, expansive use of glass, and new interior/exterior relationships - were also central to the solar heat gain and distribution innovations of many Living with the Sun entries. In fact, in this competition we can glimpse a 
moment where the lifestyle project of modern design proposes to produce a new relationship to technology and, by simple extrapolation, to the material, environmental, and political issues that accompanied the slow depletion of fossil fuel resources.

The Association for Applied Solar Energy [AFASE] was primarily a scientific organization, formed in early 1954 to promote investment in solar energy technologies. In November of the following year, the AFASE held a five-day World Symposium on Applied Solar Energy in Phoenix. The symposium acted as a clearing-house for dynamic, multi-faceted, and international discussion of the use of solar energy. Sessions were held on solar water heaters and solar furnaces, on solar-powered water desalinization systems, and on the use of the sun's energy for the growth of micro-food sources in famine inflicted areas (Putnam 213). If the primary focus of the symposium was to demonstrate the usefulness of the sun's energy in applications relevant to developing regions where electricity was not readily available, a secondary ambition was to present solar power as a "complementary resource" (Daniels); complementary, that is, to large-scale and infrastructural developments that supported the generation of electricity through fossil fuels or - at this point still experimentally - nuclear power. As a complementary resource, the possibility of using solar collection units to heat residential buildings was one of the most promising applications, and the session on "Solar House Heating" reviewed a number of experiments in solar collection techniques.

For the most part, the 1955 session reiterated presentations made at a five-day "coursesymposium" held at the Massachusetts Institute of Technology in 1950 entitled "Solar Energy for Space Heating", organized jointly by the Department of Chemical Engineering and the Department of Architecture. In 1939, the Chemical Engineering department built what became known as the First MIT Solar House: a one-room laboratory shed with a solar collector spanning the south-facing pitched roof. Though not sophisticated architecturally, the collector unit established the basic technological parameters of solar collection: glass plates enclosed a few feet of rock and insulation, through which water (or, later, air) was pumped. In the 1939 house, the heated water drained down to a large tank in the heavily insulated basement. A ventilation system drew cool air over the hot water and then back into the house as warm air. As with most solar collector systems, this required the use of electricity and it was therefore an active solar system. The experiment was largely successful, able to maintain a temperature of $72^{\circ}$ throughout the winter, though not economical due to the cost of materials and construction (Hesselshwerdt 99).

After the war, and following a failed second experiment, the Third MIT Solar House of 1949 became something of an industry standard for solar space heating; it was largely to celebrate this project that the 1950 'course-seminar' was held. The house was a simple bar building, constructed with triple-glazed south facing windows that, following a careful curtain-operation regime, retained most of the absorbed solar heat. A heavily insulated a-frame collector spanned the length of the roof, with a water tank inside of it. Instead of a forced air system heating the air over the water, the hot water itself circulated through radiant ceiling panels, which reduced the electricity needed for water circulation (Hesselshwerdt 102). The combination of passive and active solar heating provided for almost $75 \%$ of the required winter heat, and the set up costs, though still far beyond that of conventional mechanical systems, was significantly less than earlier experiments (Butti and Perlin 211).

Though not designed by an architect, the Third MIT House reflected knowledge of architectural experiments in passive solar heat gain, and was an explicit attempt to merge this architectural technology with that of the solar collector unit. George Fred Keck's houses outside Chicago from the mid-30s were perhaps the best known passive solar houses in this period - both Keck and one of his clients presented papers at the MIT conference. Keck's solar houses, of which the 1941 Duncan House is exemplary, were simple bar buildings with large south-facing windows in every room. Keck's designs were popular with developers; at a time when modern design was just beginning to catch on in mainstream building culture, they made an argument for the relationship between the open plan, full glazing, and reduced cost of heating that was attractive to many home-buyers: the modern house, if nothing else, had the benefit of being warmer (Menocal 15). Indeed, we can think of the Third MIT House as a flat-roofed, open-plan house, it's hipped roof profile being the result of the design of the collector rather than of the house itself. George Lof, an engineer who worked on the First MIT house and would develop solar collector houses in Denver, Los Angeles, and Dallas, suggested at the 1955 AFASE symposium that, by virtue of the flat roof, the freedom of internal cubic arrangements, and consequent potential for efficiency in heat storage and distribution, "the use of a modern idiom could increase annual solar heating provision by as much as $25 \%$ " (Lof 202). The purpose of 
the Living with the Sun competition was, quite self-consciously, to integrate the design the collector units with that of the modern house itself.

Before discussing the competition, however, a few words as to its political and institutional context. For if, as has been indicated, the AFASE was a primarily scientific and industrialist organization, it was at the same time formed out of a complex of geopolitical concerns. The period right after World War II, it should be remembered, was one of a severe worldwide energy shortage, the war not only depleted known resource deposits, it also disrupted systems of production and distribution. In 1950, President Truman established the Materials Policy Commission to, as the directive put it, "answer the question: has the United States of America the material means to sustain its civilization?" ("Resources for Freedom" 1 ). One of the major proposals of the Commissions report, issued in mid-1952, was that the government encourage the development of alternative energies - nuclear power, solar power, and synthetic fuels - to alleviate dependence on foreign oil. In this early 50 s moment, the technology for all of these methods was relatively undeveloped, and the summary of the report states that "the direct utilization of solar energy [is] the most important contribution technology can make to the solution of the materials problem" ("Resources for Freedom" 54) and further that the "comfort heating" of the single-family house is the most appropriate application of the use of solar power (Putnam 216).

While this could have led to widespread experimentation with solar energy, in fact the reception of the report was seriously compromised by the victory of Eisenhower, in part through support of the energy industry, in the 1952 presidential elections. Eisenhower set up his own Cabinet Committee on Energy Supplies and Resource Policy in early 1953 which claimed that, in fact, there was no short term energy problem to contend with (Strum 50). Following the administration's rhetoric of limiting intervention in the economy, The Cabinet Committee proposed that "the use of alternative energy sources should be as far as possible that of the free choice of the consumer" ("Energy Supplies and Resources Policy: Report of the Cabinet Committee" qtd. In Strum 39) and the burden of research and development should be placed on industry rather than on government.

The Association For Applied Solar Energy was formed in response to both the initial elation at the prospect of increased funding for solar research and the disappointment of seeing that funding source evaporate. The basic proposal of the organization was to prove the economic viability of solar power in the context of an expected rise in energy costs. Simply put, the set-up costs for solar power were only justifiable when the real costs of nuclear power or oil were passed on to the consumer. However, the Eisenhower administration's retreat from the funding of 'alternative energy' sources did not extend to the corporate interests lobbying for a new nuclear power industry: reactor design, fissionable material, and personnel were all freely shared freely between government research groups and Westinghouse, GE, and others. Furthermore, the development of a post-war oil economy was dependent on associated political and military activity, the most obvious example being the CIA engineered coup in Iran in 1953, only months after Eisenhower took office, which effectively delivered $40 \%$ of the Iranian oil fields to American companies (Kinzer 215). The various economic and geo-political machinations to mask or effectively reduce the costs of industrial energy production found no corollary in the distributed potential of solar energy generation.

In discussing the Living with the Sun competition, it is important to recognize that the AFASE was desperate to maintain its relevance in light of an inability to establish an economic logic for the use of solar collection. The competition, as a result, seeks to establish a cultural movement, a solar lifestyle that would ride on the heels of the emerging modern sensibility in architecture culture. The Chairman of the competition jury, Pietro Belluschi, described this dynamic as follows: "The way in which architects succeed in integrating [the utilization of solar energy] with the design of buildings and giving it aesthetic appeal will have a great effect on the rapidity with which it will receive general acceptance" ("Living with the Sun" vi). The competition brief indicated that the entrants were free to assume that "the occupants of the house, having great respect for the sun and its influence on their way of life, would feel strongly that the energy of the sun should be harnessed," thus the alteration of the design for this purpose would be welcomed ("Living with the Sun" iv). The progress of modern architecture, both of these statements assume, would be productively inflected by the design and technology concerns of solar heating processes.

The competition was relatively ambitious in its definition of a solar house; the brief stipulated that energy from collectors would provide for year-round water heating, including heating the pool, as well for winter space heating. The technological specifications proposed a basic 
collector unit, based on the standard MIT module but with (not-yet-available) plastic sheeting instead of multi-paned glass as the cover. A precise angle and square footage of collector were stipulated, and entries were to provide a cubic diagram analyzing heating requirements and ventilation parameters, as well as a proposal for heat storage ("Living with the Sun" v).

The projects premiated by the jury demonstrate an integrated approach to the design of the house and of the solar collectors. The winning entry, by Peter Lee of Bliss and Campbell in Minneapolis, was a straightforward rectangular shell surrounding a concrete and glass box, with outer walls of brick screens and patios covered by mechanically-tiltable solar-collection louvers. It was cited by the jury for the "logic of its solar equipment, which acts in double capacity of shade louvers in summer and heat collectors in winter" and also for the "direct organization of the plan" ("Living with the Sun" vii). The second place winner, by Anna Campbell Bliss, a principal in the same Minneapolis firm, is dramatically different in design [fig 25]. More concerned with formally expressing its energy generating capacity, optimally angled panels form the exterior walls; as the jury comments put it: "the solar collectors themselves produce the architectural quality of the house... there is a consistency of approach and directness which the jury liked, however the north wall slopes in the same manner as the south wall, without having the same reasons for doing so, thereby becoming a cliché rather than a logical solution" ("Living with the Sun" vii). Thus presumably the reason this entry is relegated to second place is because the integrated architectural-technological design logic is not carried to its conclusion.

Beyond these winning entries, three important manifestations of the conflation of modern architecture and solar technology are evident in the 60 published competition panels. The first involves the design of the solar collector itself, as the winning entry's louver-collectors already indicate. Two selected entries from the team of John Morphett and Hanford Yang, MIT architecture students, stand out in this regard. Their third place entry has a roof covered with a visually dynamic array of diamond-shaped collectors. Their other entry has a more stoic alternating bank of extruded cone shaped collectors, in staggered rows. Both designs use the collector as a functional ornament and to express planometric arrangements.

Engagement with the roofline provides a second prominent connection. Some exemplary entries in this regard include Manuel Dumlao's channeled flat solar roof, whose heat distribution ducts allow the collectors to be leaned against them at the optimum angle. Evison, Lester, and Ottum's entry pitches the roof slightly, angling the collector units on one side and using the slope of the other to distribute water through radiated ceiling panels. The most dramatic is Ashok Bhavnani's space frame entry, in which the floating tensegrity structure surrounds the rectangular house with multiply angled panels - those at ideal collection angle have collectors embedded in them, and the space between the frame and the house are used as heat storage.

Finally, a number of interesting entries separate solar collection completely; what is compelling here is how these entries on the one hand act as a foil for the 'solar lifestyle' and on the other hand replicate it without explicit technological engagement. In a proposal by Enis Kortan, an architect in Marcel Breuer's office, a staid rectangular house is separated from the garage by a pool area. Along side and above the pool, like a billboard, a large panel of collectors generates adequate energy to meet all of the requirements. The project received an honorable mention; the jury commented that it was "worthy of mention because of the strong statement made by the solar-collecting devices, although it was felt that such a feature should be more sculptural than indicated" ("Living with the Sun" vii). The entry by Morton Karp, also receiving an honorable mention, was of the most obviously Wrightian in the competition. Karp's heat collection system was separate from the house itself, involving a "hot pit" in the side yard, where collectors were dug into the ground at an optimum angle and reflected onto glass covered gravel beds. In both cases the connection of technological to design innovation is abstract, if not ideological.

Numerous architectural tropes - the open plan, the integration of interior and outside spaces, and prominent use of breezeways, screens and moveable partitions - connect the Living with the Sun projects to the discourse on the modern house - if the book does not, in fact, represent one of the more innovative and comprehensive compendiums of residential design in the period. At the same time, Living with the Sun is clouded by a fantasy of the technological improvement of solar collectors leading to economic efficiency - which is to say, a sort of science fiction in which solar energy resolves its own economic-technological conundrums, rather than being reconfigured, as a cultural and technological project, relative to events and ambitions in the geo-political sphere.

Bracketed out of the above discussion is the invention of the photovoltaic cell at Bell Laboratories in early 1954, unveiled to the public at the 1955 AFASE conference, which would eventually change the discussion of solar power. The technological discourse around 
photovoltaics is far removed from that of solar collection or the passive absorption of heat: the pv cell reacts to light, not heat, and converts light directly into electricity; furthermore, the use of an expensive, production heavy panel is more in line with the industrial use of nuclear power than the distributed potential of south-facing windows or solar collectors.

Indeed, the potential impact today of the photovoltaic panel on the culture of architectural design, as with most technology that claims to be 'environmental' or 'sustainable', is slight at best. Unlike the technologies of solar collection, the snap-on system of photovoltaics does not require that architects engage complicated relationships between design and technological efficiency. The most hypocritical - and, unfortunately, one of the most prominent - proposals of the growing 'sustainable' tendency in architecture today is the elision of epistemological, cultural, and ethical issues for the ability to, as with the photovoltaic panel, specify a new set of purportedly more efficient materials and products. In this context, the proposals in Living with the Sun, in their attempt to design a response to political problems, are, one hopes, tantalizing for practitioners and historians alike.

\section{References}

Butti, Ken and John Perlin. A Golden Thread: 2500 Years of Solar Architecture and Technology. New York: Van Nostrand Reinhold, 1980.

Daniels, Farrington. "The Sun's Energy." World Symposium on Applied Solar Energy. Menlo Park, CA: Association for Applied Solar Energy, Stanford Research Institute, University of Arizona, Phoenix, 1955. vol. 1, np.

Hesselschwerdt, August L. "Performance of the MIT Solar House." Space Heating with Solar Energy: Proceedings of a Course-Symposium held at the Massachusetts Institute of Technology, August 21-26, 1950. Ed. Richard W. Hamilton. Cambridge, MA: Massachusetts Institute of Technology/Bemis Foundation, 1954. 99-106.

Kinzer, Stephen. All the Shah's Men: An American Coup and the Roots of Middle East Terror. Hoboken NJ: John Wiley and Sons, 2003.

Living with the Sun. Pheonix, AZ: Association for Applied Solar Energy, 1958.

Löf, George and James Hunter. "The Boulder House and the Denver House."

Proceedings of the World Symposium on Applied Solar Energy, Phoenix, Arizona, November 15, 1955. Menlo Park, CA: Stanford Research Institute, 1956. 189-204.

Menocal, Narciso G. Keck and Keck Architects. Madison, WI: University of Wisconson/ Elvejhem Museum of Art, 1980.

Putnam, Palmer. "The Promise of Technology: The Possibilities of Solar Energy" Resources For Freedom: A Report to the President. Washington, D.C.: US Government Printing Office, 1952. v.1. 213-220.

Resources for Freedom: Summary of Volume 1 of a Report to the President by the President's Materials Policy Commission. Washington, D.C.: US Government Printing Office, June 1952.

Strum, Harvey. "Eisenhower's Energy Policy" The Public Historian 6.2 (Spring 1984), 36-54. 